\title{
Mechanism of Action of Anti-C1-Inhibitor Autoantibodies: Prevention of the Formation of Stable C1s-C1-inh Complexes
}

\author{
Shiping He, ${ }^{1}$ Robert B. Sim, ${ }^{2}$ and Keith Whaley ${ }^{1}$ \\ ${ }^{1}$ Department of Microbiology and Immunology, University of \\ Leicester, Leicester, U.K. \\ ${ }^{2} \mathrm{MRC}$ Immunochemistry Unit, Department of Biochemistry, \\ University of Oxford, Oxford, U.K. \\ Communicated by K. Austen. Accepted December 15, 1997.
}

\begin{abstract}
Background: Acquired Cl-inhibitor (Cl-inh) deficiency is usually associated with the presence of circulating $\mathrm{Cl}$-inh autoantibodies. These autoantibodies have been shown previously to bind to two synthetic peptides corresponding to $\mathrm{Cl}$-inh amino acid residues $438-449$ (peptide 2) and 448-459 (peptide 3) but not to peptide 1 (residues 428-440).

Materials and Methods: Affinity-purified Cl-inh autoantibodies from two patients with acquired $\mathrm{Cl}$-inh deficiency were studied for their effects on the inhibition of $\mathrm{Cls}$ activity by $\mathrm{Cl}$-inh using SDS-PAGE and hydrolysis of a synthetic ester.

Results: Functional studies confirmed that the anti-C1inh autoantibodies abrogated $\mathrm{Cl}$-inh activity, and their maximum effect was produced when the concentrations of $\mathrm{Cl}$-inh and autoantibody were approximately
\end{abstract}

equimolar. The autoantibodies prevent the formation of the $\mathrm{Cls}-\mathrm{Cl}$-inh complex, but they do not dissociate the preformed complex, suggesting that the autoantibodies act prior to the formation of the enzyme-inhibitor complex. In the presence of autoantibodies, $\mathrm{Cl}$ s cleaves $\mathrm{Cl}$ inh, and a stable covalent bond between $\mathrm{Cls}$ and $\mathrm{Cl}$-inh does not form. Peptides 2 and 3, but not peptide 1 inhibited autoantibody activity, thus $\mathrm{Cl}$-inh inhibitory activity for Cls was expressed fully.

Conclusions: Our data indicate that the anti-C1-inh autoantibodies convert $\mathrm{Cl}$-inh to a substrate by preventing the formation of the stable covalent protease-serpin complex. The data also suggest a possible therapeutic use for peptides 2 and 3 or their derivatives in the management of patients with type II acquired angioedema (AAE).

\section{Introduction}

During activation of the serum complement system, complement component $\mathrm{Cl}$ binds to immune complexes or other complement activators. Binding of $\mathrm{Cl}$ to a target results in activation of the complement serine proteases $\mathrm{Clr}$ and $\mathrm{Cls}$, which are subunits of the $\mathrm{Cl}$ complex. Cls subsequently cleaves complement

Shiping He's present address is Department of Medicine, University of Birmingham, Birmingham, England.

Address correspondence and reprint requests to: Dr. K. Whaley, Department of Microbiology and Immunology, University of Leicester, University Road, Leicester, LE1 9HN, U.K. Phone: 44-116-252950; Fax: 44-116-2525030. components $\mathrm{C} 4$ and $\mathrm{C} 2$. The activity of $\mathrm{Clr}$ and $\mathrm{Cls}$ is controlled by the serpin $\mathrm{Cl}$-inhibitor $(\mathrm{Cl}$ inh $)^{3}$, which is the sole circulating inhibitor of $\mathrm{Cl}$ subcomponents $\mathrm{Clr}$ and $\mathrm{Cls}(1)$. Cl-inh has a calculated polypeptide molecular weight of $\mathbf{5 2 . 8 4}$ $\mathrm{kDa}$ but is seen in SDS-PAGE as a glycosylated popypeptide of apparent $\mathrm{Mr}$ 105-115 kDa. Data from neutron-scattering studies showed that glycosylated $\mathrm{Cl}$-inh has $\mathrm{Mr} 71 \mathrm{kDa}$ in nondenaturing conditions (2). $\mathrm{Cl}$-inh regulates $\mathrm{Cl}$ activity in two ways: it binds reversibly to precursor $\mathrm{Clr}$ and $\mathrm{Cls}$ to prevent autoactivation (3), and it binds to activated $\mathrm{Clr}$ and $\mathrm{Cls}$ to inhibit their enzymatic activity (4). During the latter reaction, 
$\mathrm{Clr}$ or $\mathrm{Cls}$ attacks $\mathrm{Cl}$-inh between residues R444 and T445 and appears to form a stable (covalent) enzyme-pseudosubstrate complex. The tetrametric $\mathrm{Cl}$-inh-Clr-Cls- $\mathrm{Cl}$-inh complex then dissociates from the $\mathrm{Cl}$ complex leaving $\mathrm{Clq}$ bound to the complement-activating particle (4). Like other serpins, C1-inh forms a stable complex with the proteases it inhibits. The serpin-protease complexes do not dissociate in SDSPAGE analysis. The precise mode of interaction of serpins and proteases is not fully established (5), but it is assumed that the protease attacks the serpin as if it were a substrate. Secondary interactions then stabilize the enzymepseudosubstrate complex. The cleavage of the pseudosubstrate can be driven to completion in nonphysiological conditions, such as high $\mathrm{pH}$.

$\mathrm{Cl}$-inh deficiency is manifest clinically as angioedema (AE) and may be inherited (HAE) or acquired (AAE). Two types of AAE have been described. Type $I$ is associated with an anti-idiotypic response to plasma or membrane immunoglobulin and occurs in patients with multiple myeloma, chronic lymphocytic leukemia, or benign monoclonal gammopathy (6). The binding of the anti-idiotype to antibody appears to cause excessive $\mathrm{Cl}$ activation with consumption of $\mathrm{C} 4$ and $\mathrm{C} 2(6)$. Excessive catabolism of $\mathrm{C} 1$-inh results in low serum levels of this protein (6). In type II AAE, autoantibodies to $\mathrm{Cl}$-inh are present (7) and serum $\mathrm{Cl}$-inh levels as judged by immunoassays are normal or only slightly reduced, but it circulates as a cleaved, functionally inactive form (8) which has an apparent $\mathrm{Mr}$ of 96 $\mathrm{kDa}$ on SDS-PAGE. In our previous study (9), we described 6 patients with type II AAE. The autoantibodies were clonally restricted and recognized an epitope $C$-terminal to the reactive site residue (R444); the epitope was centered on the sequence QQPF (residues 452-455). The possibility that these antibodies recognized a second, structurally similar epitope (LLVF, residues 446449) was also noted. In this report we studied the mechanism of action of two of these autoantibodies and show that both prevent the formation of a stable Cls-Cl-inh complex, although they still permit cleavage of $\mathrm{Cl}$-inh by $\mathrm{Cls}$ at the reactive site $(\mathrm{Pl})$ residue.

\section{Materials and Methods}

Patients

Two patients (Patients 1 and 2; see Table 1 in ref. 9) with type II AAE were studied. Both patients had immunoglobulin (Ig)G kappa anti-C1-inh autoantibodies in their sera. The clinical details and the characteristics of the antibodies are described by He et al. (9). Both autoantibodies recognized the synthetic peptides corresponding to residues 438-449 of $\mathrm{Cl}$-inh (SAISVARTLLVFpeptide 2) and 448-459 (VFEVQQPFLFVL-peptide 3 ) but not a synthetic peptide corresponding to residues 428-440 (TETGVEAAAASAI-peptide 1). Both antibodies bound better to peptide 3 and the use of substituted peptides and protein modeling suggested that the epitope comprised the tetrapeptide Q452, Q453, P454, F455 (9). It was concluded that binding to peptide 2 was due to the structural similarity of the tetrapeptide L446, L447, V448, F449 with Q452-F455 (9).

\section{Synthetic Peptides}

Three peptides (peptides 1, 2, and 3; see above) were obtained from Alta Biosciences (Department of Biochemistry, University of Birmingham, Birmingham, England).

\section{Preparation of IgG from Serum by Protein $G$ Affinity Chromatography}

Normal and patients sera $(10 \mathrm{ml})$ were incubated with $5 \mathrm{ml}$ protein G Sepharose (Pharmacia, Milton Keynes, U.K.) at $4^{\circ} \mathrm{C}$ on a rotating stirrer. After $30 \mathrm{~min}$, the mixture was poured into a $15-\mathrm{ml}$ column and the nonadsorbed protein washed through with phosphate-buffered saline (PBS) (pH 7.4) until the absorbance at $280 \mathrm{~nm}$ was 0.002 . The column was eluted using 100 $\mathrm{mM}$ glycine- $\mathrm{HCl}, \mathrm{pH} \mathrm{2.9}$, and fractions containing protein were adjusted to $\mathrm{pH} 7.4$ by addition of $2 \mathrm{M}$ Tris- $\mathrm{HCl}$ buffer ( $\mathrm{pH} \mathrm{8.0)}$ ) prior to dialysis against PBS (pH 7.4).

\section{Affinity Purification of Anti-C1-Inhibitor Autoantibodies}

Human Cl-inh (5 mg in $2 \mathrm{ml}$ PBS) was mixed with $2 \mathrm{ml}$ cyanogen bromide-activated Sepharose (Pharmacia) according to the manufacturer's instructions. The coupling efficiency was $83 \%$. IgG $(5.0 \mathrm{mg})$ purified from patient's serum was incubated with $1 \mathrm{ml}$ of $\mathrm{Cl}$-inh-Sepharose at $4^{\circ} \mathrm{C}$ on a rotating stirrer for $30 \mathrm{~min}$. The mixture was poured into a column, the gel washed extensively with PBS to remove nonspecifically bound IgG molecules, and then washed with 4 column volumes of water. The bound anti-Clinh autoantibody was eluted with $3 \mathrm{M} \mathrm{MgCl}_{2}$. 
The eluted protein was dialyzed against PBS prior to use. The concentration of IgG was determined spectrophotometrically using an extinction coefficient $\left(\mathrm{OD}_{280} 1 \mathrm{mg} / \mathrm{ml}, \mathrm{l} \mathrm{cm}=1.4\right)$ (10). Between 0.07 and $0.1 \mathrm{mg}$ of anti-Cl-inhibitor autoantibody could be purified from $5.0 \mathrm{mg}$ total IgG. These antibody preparations contained only IgG as shown by SDS-PAGE, and they bound to solid-phase $\mathrm{Cl}$-inh but not to bovine serum albumin (BSA). Binding to solid-phase $\mathrm{Cl}$-inh was inhibited by fluid-phase $\mathrm{Cl}$-inh.

\section{Purification of Cl-Inhibitor and Cls and Radiolabeling}

C1-inh was purified from fresh human plasma using the method of Pilatte et al. (11). Activated Cls was purified using the method of Sim (12). SDS-PAGE analysis using $7.5 \%$ gels run under nonreducing conditions showed that $\mathrm{Cl}$-inh had an apparent molecular weight of $115 \mathrm{kDa}$ with a minor band at $96 \mathrm{kDa}$, whereas under reducing conditions, $\mathrm{Cl}$-inh appeared as a single band of $105 \mathrm{kDa}$. Under reducing conditions, $\mathrm{Cls}$ appeared as two bands of $58 \mathrm{kDa}$ and $27 \mathrm{kDa}$, whereas under nonreducing conditions, it appeared as a single band of $85 \mathrm{kDa}$. Concentrations of $\mathrm{Cl}$-inh and $\mathrm{Cls}$ were determined using extinction coefficients $\left(\mathrm{OD}_{280}, 1 \mathrm{mg} / \mathrm{ml}, 1 \mathrm{~cm}\right)$ of 0.36 for Cl-inh (13) and 0.95 for Cls (14). For the calculation of molar concentrations of $\mathrm{Cl}$ inh and $\mathrm{Cls}$, values of $105 \mathrm{kDa}$ and $85 \mathrm{kDa}$, respectively, were used.

$\mathrm{Cls}$ was radiolabeled with $\mathrm{Na}^{125} \mathrm{I}$ (Amersham International, Little Chalfont, U.K.) using Iodobeads (Pierce and Warriner, Chester, Cheshire, U.K.) (15). Free iodide was separated from the labeled protein by gel filtration on a PD-10 (Sephadex G-25) column (Pharmacia). The specific activity of ${ }^{125}$ I-labeled $\mathrm{Cls}$ was $127,000 \mathrm{cpm} / \mu \mathrm{g}$.

\section{SDS-PAGE, Autoradiography, and Western Blotting}

Gels of $10 \%$ and $7.5 \%$ w/v acrylamide were used according to the method of Laemmli (16). Samples were boiled for $2 \mathrm{~min}$ in $1: 1(\mathrm{v} / \mathrm{v})$ sample buffer $(0.125 \mathrm{M}$ Tris base, $4 \%$ (v/v) SDS, and $20 \%(\mathrm{v} / \mathrm{v})$ glycerol pH6.8) in the absence or presence of $5 \%(\mathrm{v} / \mathrm{v}) 2$-mercaptoethanol (Sigma). After electrophoresis, gels were stained with Coomassie Blue to visualize protein bands, dried prior to autoradiography, or used for Western blotting (17).

For autoradiography, gels were dried, wrapped in Clingfilm (Borden, North Baddesley, Southampton, U.K.) and exposed to X-ray film (Blue Sensitive Film, Genetic Research Instrumentation Ltd, Dunmow, England) in the dark at room temperature.

For Western blotting, proteins were transferred to nitrocellulose membranes (Hybond-Super; Amersham International) from polyacrylamide gels in $25 \mathrm{mM}$ Tris/ $192 \mathrm{mM}$ glycine buffer containing $20 \%(\mathrm{v} / \mathrm{v})$ methanol and $0.1 \%(\mathrm{w} / \mathrm{v})$ SDS at $4^{\circ} \mathrm{C}$ using a current of $200 \mathrm{~mA}$. Transfer was completed in $6 \mathrm{hr}$. After blotting, the membrane was washed in $10 \mathrm{mM}$ Tris- $\mathrm{HCl}(\mathrm{pH} \mathrm{8.0)}$ containing $150 \mathrm{mM} \mathrm{NaCl}, 1 \mathrm{mM}$ EDTA, and $0.1 \%(\mathrm{v} / \mathrm{v})$ Triton $\times 100$ (rinse buffer). Membranes were then incubated $\left(6 \mathrm{hr}\right.$ at $\left.4^{\circ} \mathrm{C}\right)$ in blocking buffer (rinse buffer containing 2\% $(\mathrm{w} / \mathrm{v}) \mathrm{BSA}$ and $0.02 \%(\mathrm{w} / \mathrm{v})$ sodium azide) to block nonspecific protein binding sites. $\mathrm{Cl}$-inh was detected by incubating $\left(2 \mathrm{hr}\right.$ at $\left.4^{\circ} \mathrm{C}\right)$ the membrane with blocking buffer containing $1 / 2,000(\mathrm{v} / \mathrm{v})$ goat anti-human $\mathrm{Cl}$-inh (Incstar, Wokingham, Berkshire, U.K.), washing the membrane ( 3 times, $15 \mathrm{~min}$ in $100 \mathrm{ml}$ for each wash) with rinse buffer, incubating $\left(2 \mathrm{hr}\right.$ at $\left.4^{\circ} \mathrm{C}\right)$ with $1 / 3,000(\mathrm{v} / \mathrm{v})$ peroxidase-labeled rabbit anti-goat IgG (Incstar) in rinse buffer containing $2 \%(\mathrm{w} / \mathrm{v}) \mathrm{BSA}$, rewashing the membrane, and then developing the reaction using the ECL System (Amersham International) according to the manufacturer's instructions. The membrane was then exposed to high-performance luminescence detection film (Hyperfilm-ELC, Amersham International). Autoradiographs were scanned using a Molecular Dynamics Scanner (Molecular Dynamics, Inc. Chesham, Buckinghamshire, U.K.), to measure the area under the curve.

\section{Effect of Anti-Cl-inh Autoantibodies on Reaction between $\mathrm{Cls}$ and $\mathrm{Cl}$-inh}

$\mathrm{Cl}$-inh, $\mathrm{Cls}$, and autoantibodies were diluted in PBS prior to their addition to reaction mixtures. Reactions were carried out in PBS containing $1 \%$ $(\mathrm{v} / \mathrm{v})$ Triton $\times 100$ at $37^{\circ} \mathrm{C}$ for $2 \mathrm{hr}$. Full details of each reaction are given in the figure legends.

\section{Kinetic Assays}

Inhibition of $\mathrm{Cls}$ activity by $\mathrm{C} 1$-inh was determined by the method of Sim and Reboul (19) with minor modifications. Briefly, Cls, Cl-inh, and autoantibodies were dialyzed against $10 \mathrm{mM}$ Tris- $\mathrm{HCl}, \mathrm{pH} 8.0$, containing $100 \mathrm{mM} \mathrm{NaCl}$ and 1 mM EDTA. The chromogen, propionyl L-lysyl 


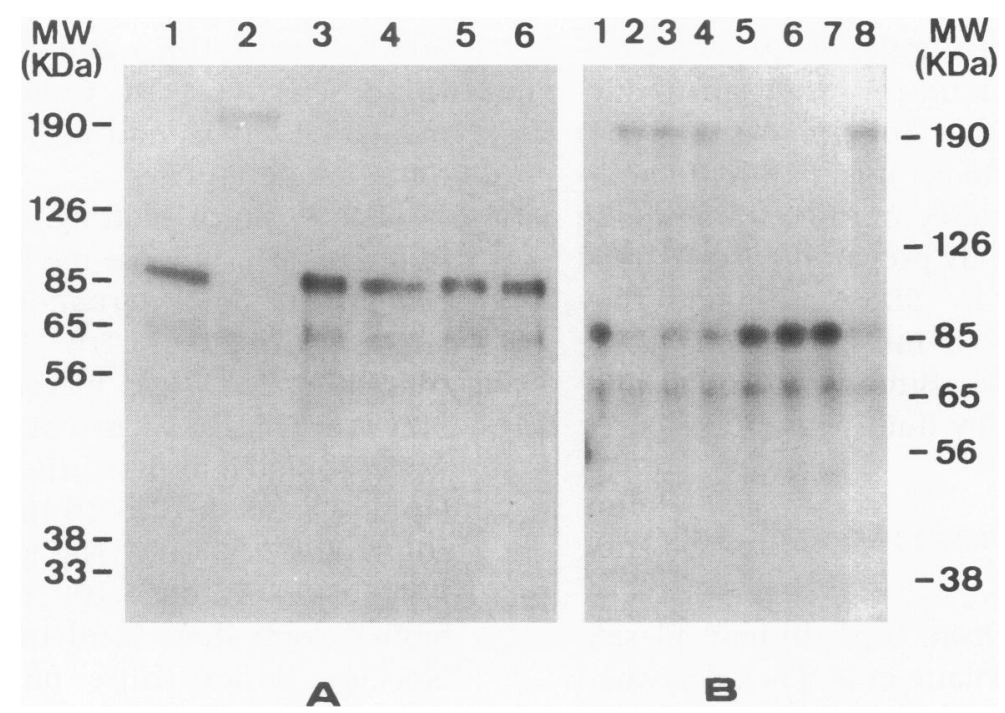

Fig. 1. Inhibition of Cls-Cl-inh complex formation by autoantibodies. All protein reagents were diluted with PBS- $1 \%$ Triton $\times 100$ and the reaction volume was set to a total volume of $40 \mu \mathrm{l}$. (A) Complete inhibition of Cls-Cl-inh complex formation by autoantibody. Fixed concentrations of both $\mathrm{Cl}$-inh $(2.1 \mu \mathrm{M})$ and ${ }^{125}$ I-labeled Cls $(1.8 \mu \mathrm{M})$ were used in the reactions. Autoantibodies were preincubated with $\mathrm{Cl}$-inh for $2 \mathrm{hr}$ at $37^{\circ} \mathrm{C}$ before addition of $\mathrm{Cls}$. Incubation was continued for a further $2 \mathrm{hr}$. The reaction was stopped by addition of SDSPAGE sample buffer and samples were analyzed by SDS-PAGE under nonreducing conditions. An autoradiograph of the dried gel is shown. The observed radioactive bands are: $>190 \mathrm{kDa}, \mathrm{Cls}-\mathrm{Cl}$-inh complex; $85 \mathrm{kDa}, \mathrm{Cls}$; $65 \mathrm{kDa}$, a form of $\mathrm{Cls}$ in which part of the heavy chain is lost $(28,29) ; 27 \mathrm{kDa}$, light chain of $\mathrm{Cls}$ dissociated from intact protein. Lane $\mathrm{l}$ : ${ }^{125} \mathrm{I}$-labeled Cls alone; lane 2: C1-inh and ${ }^{125} \mathrm{I}-\mathrm{la}$ -

( $\epsilon$-benzyloxycarbonyl) glycyl l-arginine p-nitroanilide hydroacetate $\left(\mathrm{C}_{2} \mathrm{H}_{5} \mathrm{CO}\right.$-Lys $(\epsilon$-Cbo $)$-GlyArg-pNA) (Immuno Ltd, Heidelberg, Germany) was dissolved in $100 \mathrm{mM}$ sodium phosphate, $\mathrm{pH}$ $8.0,100 \mathrm{mM} \mathrm{NaCl}$, and $15 \mathrm{mM}$ EDTA to a concentration of $28 \mu \mathrm{M}$.

In order to determine the $50 \%$ inhibitory concentration of $\mathrm{Cl}$-inh, $\mathrm{Cl}$ s was used at a fixed concentration $(23.5 \mathrm{nM}$ in a final reaction volume of $3 \mathrm{ml}$ ) with the concentration of $\mathrm{Cl}$-inh ranging from 0 to $30.5 \mathrm{nM}$. This series of reactions was incubated at $37^{\circ} \mathrm{C}$ for $30 \mathrm{~min}$ before adding the chromogen to a final concentration of $8.4 \mu \mathrm{M}$, after which the absorbance changes at $405 \mathrm{~nm}$ were recorded at 20-sec intervals for 6 min using a Perkin Elmer spectrophotomer. Residual Cls activity (\%) was calculated using the equation: $[1-(\{x-y\} / x)] \times 100$, where $x=$ beled C1s; lane 3: Patient 1 autoantibody $(0.9 \mu \mathrm{M})$, $\mathrm{C} 1$-inh, and ${ }^{125}$ I-labeled C1s; lane 4: Patient 1 autoantibody $(0.9 \mu \mathrm{M})$ and ${ }^{125}$ I-labeled Cls; lane 5: Patient 2 autoantibody $(0.9 \mu \mathrm{M}), \mathrm{Cl}$-inh, and ${ }^{125} \mathrm{I}$-labeled C1s; lane 6: Patient 2 autoantibody $(0.9 \mu \mathrm{M})$ and ${ }^{125}$ I-labeled Cls. (B) Inhibition of $\mathrm{Cl}$-inh activity by different concentrations of patient 1 autoantibody. The concentrations of $\mathrm{Cl}$-inh and ${ }^{125} \mathrm{I}$-labeled $\mathrm{Cls}$ used in this experiment were the same as in A. Lane 1: ${ }^{125}$ I-labeled $\mathrm{Cls}$ alone; lane 2: $\mathrm{Cl}$-inh and ${ }^{125}$ I-labeled Cls; lane 3: autoantibody $(0.07 \mu \mathrm{M})$, $\mathrm{Cl}$-inh, and ${ }^{125}$ I-labeled Cls; lane 4: autoantibody $(0.17 \mu \mathrm{M}), \mathrm{Cl}$-inh, and ${ }^{125}$ I-labeled Cls; lane 5: autoantibody $(0.33 \mu \mathrm{M}), \mathrm{Cl}$-inh, and ${ }^{125}$ I-labeled Cls; lane 6: autoantibody $(0.75 \mu \mathrm{M}), \mathrm{Cl}-\mathrm{inh}$, and ${ }^{125} \mathrm{I}-$ labeled Cls; lane 7: autoantibody $(0.92 \mu \mathrm{M}), \mathrm{Cl}$-inh, and ${ }^{125} \mathrm{I}$-labeled Cls; lane 8; normal IgG $(1.0 \mu \mathrm{M})$, $\mathrm{Cl}$-inh, and ${ }^{125}$ I-labeled Cls.

slope of Cls alone and $y=$ slope of Cls in the presence of $\mathrm{C} 1$-inh.

\section{Results}

Effect of Anti-Cl-inh Autoantibodies on Cls-Cl-inh Complex Formation

Incubation of unlabeled C1-inh with ${ }^{125}$ I-labeled $\mathrm{Cls}$ resulted in the formation of the $\mathrm{Cls}-\mathrm{Cl}$-inh complex (Fig. 1A). When anti-Cl-inh autoantibody was preincubated with $\mathrm{Cl}$-inh prior to the addition of ${ }^{125} \mathrm{I}$-labeled $\mathrm{Cls}$, the $\mathrm{Cls}-\mathrm{Cl}$-inh complex was not seen. As a control experiment, $\mathrm{Cls}$ was incubated with the two anti-Cl-inh autoantibodies without $\mathrm{Cl}$-inh. This had no effect on the appearance of C1s in SDS-PAGE analysis. The effect of the autoantibodies on $\mathrm{Cl}$-inh-Cls 
interaction was dose-dependent and for total inhibition of Cls-Cl-inh complex formation, approximately equimolar concentrations of autoantibody antigen binding sites and $\mathrm{Cl}$-inh were required (Fig. 1B). Normal IgG did not influence the formation of the $\mathrm{Cls}-\mathrm{Cl}$-inh complex (Fig. 1B).

Incubation of peptides 2 or 3 with the autoantibodies prior to their incubation with $\mathrm{Cl}$-inh blocked the effect of the autoantibodies as shown by the formation of the Cls-Cl-inh complex. Peptide 1 had no effect on the activity of the autoantibodies (Fig. 2).

\section{Effect of Anti-Cl-inh Autoantibodies on Stability of Cls-C1-inh Complex}

When anti-C 1 -inh autoantibody was added after the incubation $\left(2 \mathrm{hr}\right.$ at $\left.37^{\circ} \mathrm{C}\right)$ of ${ }^{125}$ I-labeled $\mathrm{Cls}$ with $\mathrm{Cl}$-inh, the $\mathrm{Cls}-\mathrm{Cl}$-inh complex was detected (Fig. 3). Prolonged incubation (up to $16 \mathrm{hr}$ at $37^{\circ} \mathrm{C}$ ) of the $\mathrm{Cls}-\mathrm{Cl}$-inh complex with anti$\mathrm{Cl}$-inh autoantibodies did not result in dissociation of the complex. During a 6-hr incubation at $37^{\circ} \mathrm{C}$, the presence of a 10 -fold molar excess of autoantibody reactive sites over $\mathrm{Cl}$-inh did not result in dissociation of the $\mathrm{Cls}-\mathrm{Cl}$-inh complex (data not shown).

\section{Effect of Anti-Cl-inh Autoantibodies on Cleavage of Cl-inh by Cls}

A $50 \%$ inhibitory amount of autoantibody was incubated with $\mathrm{Cl}$-inh for $2 \mathrm{hr}$ at $37^{\circ} \mathrm{C}$. Following the addition of different concentrations of $\mathrm{Cls}$, the tubes were incubated at $37^{\circ} \mathrm{C}$ for a further $3 \mathrm{hr}$. The reaction products were separated by SDS-PAGE and then blotted onto nitrocellulose, $\mathrm{Cl}$-inh was detected by sequential incubations with primary antibody, goat anti-human C1-inh, secondary antibody, and rabbit anti-goat IgG conjugated with horse-radish peroxidase, followed by detection using the ECL system. In the presence of either autoantibody, the intensity of the $96 \mathrm{kDa}$ band (cleaved form) increased whereas the intensity of the $115 \mathrm{kDa}$ band (uncleaved form) decreased with increasing concentration of Cls (Fig. 4A). A small proportion (approximately $10 \%$ ) of the purified $\mathrm{Cl}$-inh was in the cleaved form. This may be due to cleavage by $\mathrm{Cls}$ or possibly another protease during purification. Scanning densitometry of the Western blot showed that as the $\mathrm{Cls}$ concentration increased, the intensity of the $96 \mathrm{kDa}$ band increased (Fig. 4D), whereas the intensity of the $190 \mathrm{kDa}$

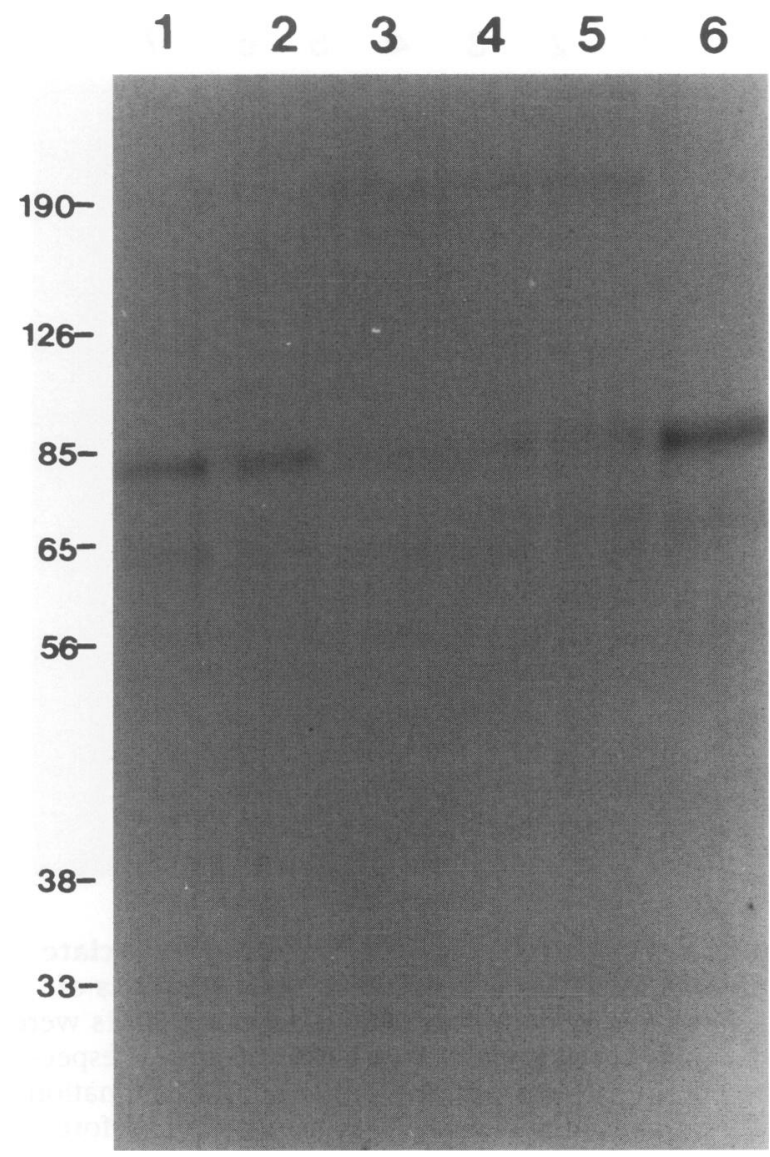

Fig. 2. The effect of synthetic peptides on anti-Cl-inh autoantibodies. The concentrations of $\mathrm{Cl}$-inh, ${ }^{125} \mathrm{I}$-labeled $\mathrm{Cls}$, and autoantibodies used in the reaction were $2.1 \mu \mathrm{M}, 1.8 \mu \mathrm{M}(75,000 \mathrm{cpm})$, and $0.5 \mu \mathrm{M}$, respectively. The concentration of the autoantibody used was calculated to cause about $50 \%$ inhibition of complex formation (see Fig. 5A). All protein reagents were diluted with PBS- $1 \%$ Triton $\times 100$ and the reaction volume was set to a total volume of $40 \mu \mathrm{l}$. Lane 1: $\mathrm{Cl}$-inh, ${ }^{125} \mathrm{I}$-labeled $\mathrm{Cls}$, and Patient 1 autoantibody. Lane 2: peptide 1 (2.6 $\mu \mathrm{M})$ was preincubated with Patient 1 autoantibody at $37^{\circ} \mathrm{C}$ for $2 \mathrm{hr}$ and then with $\mathrm{Cl}$-inh for a further $2 \mathrm{hr}$ before addition of ${ }^{125} \mathrm{I}$-labeled C $1 \mathrm{~s}$. Incubation was then continued for a further $3 \mathrm{hr}$. Lane 3: as in lane 2, except that peptide $2(2.6 \mu \mathrm{M})$ was used instead of peptide 1 . Lane $4:$ the same as in lane 2 , except peptide $3(2.6 \mu \mathrm{M})$ was used instead of peptide 1. Lane 5: $\mathrm{Cl}$-inh and ${ }^{125} \mathrm{I}$-labeled $\mathrm{Cls}$; lane 6:

${ }^{125} \mathrm{I}$-labeled $\mathrm{Cls}$ alone. The same results were obtained with the autoantibody from Patient 2.

band ( $\mathrm{Cls}-\mathrm{Cl}$-inh complex) only increased until the $\mathrm{Cls}$ concentration reached approximately $0.7 \mu \mathrm{M}$ (Fig. 4A lane 6; Fig. 4D). At higher concentrations of $\mathrm{Cls}$ the intensity of this band remained constant. In this and other experiments we were never able to produce complete cleav- 


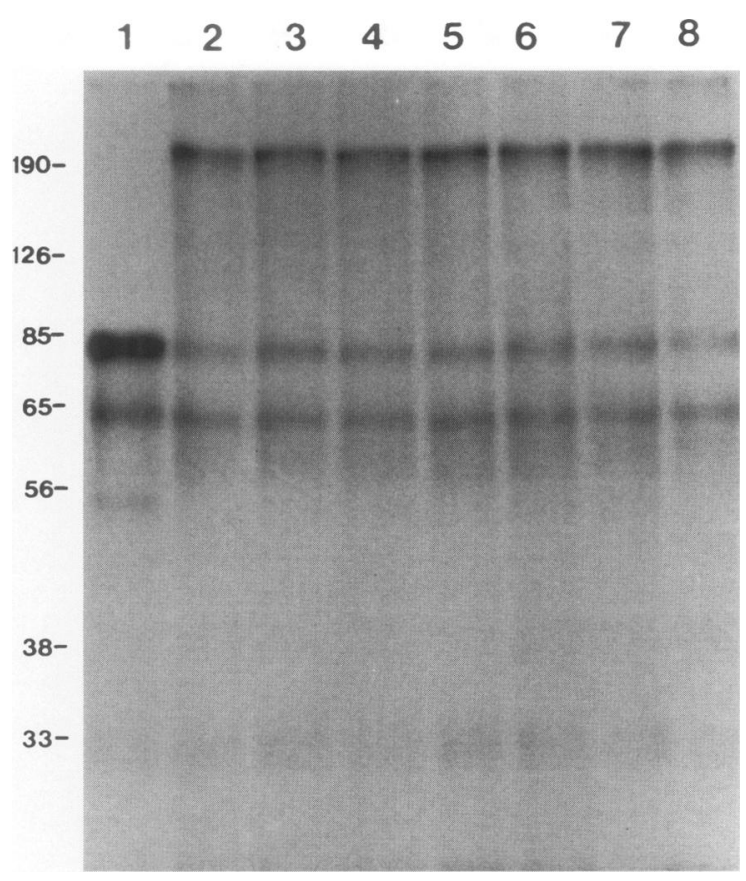

Fig. 3. Failure of autoantibodies to dissociate the C1-inh-C1s complex. The concentrations of $\mathrm{Cl}$-inh and autoantibodies and ${ }^{125}$ I-labeled $\mathrm{Cls}$ were $2.1 \mu \mathrm{M}, 0.9 \mu \mathrm{M}$, and $1.8 \mu \mathrm{M}(75,000 \mathrm{cpm})$, respectively. In the case of $\mathrm{Cls}-\mathrm{Cl}$-inh complex formation, $\mathrm{Cl}$-inh was preincubated with Cls for $2 \mathrm{hr}$ before addition of autoantibody. The reaction volume was $40 \mu \mathrm{l}$ in PBS-1\% Triton $\times 100$. Lane $1:{ }^{125}$ I-labeled $\mathrm{Cls}$ alone; lane 2: $\mathrm{Cl}$-inh and ${ }^{125} \mathrm{I}$-labeled $\mathrm{Cls}$ incubated $2 \mathrm{hr}, 37^{\circ} \mathrm{C}$; lanes 3-8: $\mathrm{Cl}$-inh and ${ }^{125}$ I-labeled $\mathrm{Cls}$ incubated $2 \mathrm{hr}, 37^{\circ} \mathrm{C}$, then autoantibody added and incubation continued for $1 \mathrm{hr}$ (lane 3), $2 \mathrm{hr}$ (lane 4), $4 \mathrm{hr}$ (lane 5), $6 \mathrm{hr}$ (lane 6), $8 \mathrm{hr}$ (lane 7), and $16 \mathrm{hr}$ (lane 8). Data shown are from Patient $\mathrm{l}$ autoantibody but an identical result was obtained with Patient 2 autoantibody.

age of $\mathrm{Cl}$-inh with a moderate (2-fold) molar excess of $\mathrm{Cls}$ and a $50 \%$ inhibitory concentration of autoantibody. Furthermore, we were never able to obtain more than $80 \%$ of $\mathrm{Cl}$-inh in SDS-stable C1s-C1-inh complexes with a 2 -fold molar excess of $\mathrm{Cls}$ in the absence of autoantibody. In order to demonstrate that complete cleavage of $\mathrm{Cl}$-inh could be produced, we used approximately equimolar concentrations of $\mathrm{Cl}$ inh at $2.1 \mu \mathrm{M}$ and autoantibody at $1.3 \mu \mathrm{M})(2.6$ $\mu \mathrm{M}$ antigen binding sites) and an excess of $\mathrm{Cls}$ $(8.8 \mu \mathrm{M})$. Under these conditions, we observed that the $115 \mathrm{kDa}$ band was completely cleaved (Fig. 4B), although even with this concentration of $\mathrm{Cls}$, in the absence of autoantibody, only approximately $80 \%$ of the $\mathrm{Cl}$-inh was incorporated into SDS-resistant $\mathrm{Cls}-\mathrm{Cl}$-inh complexes. This observation suggests that a proportion of the purified $\mathrm{Cl}$-inh had been partially denatured, or altered in conformation such that it was not cleaved by $\mathrm{Cls}$ or that the complex formed was reversible on SDS-PAGE. The autoantibody may therefore induce the correct conformation for Cls cleavage or may simply drive forward the reaction towards cleavage and an irreversible state.

Under reducing conditions, uncleaved $\mathrm{Cl}$ inh (105 kDa) and cleaved Cl-inh (96 kDa) could not be separated by SDS-PAGE on $7.5 \%$ gels; they appeared as a single, broad band along with two bands of 52 and $25 \mathrm{kDa}$ (Fig. 4C). Other bands were not seen. These results were confirmed using two anti- $\mathrm{Cl}$-inh autoantibodies and the sizes of the fragments were confirmed using three sets of protein markers (Sigma C3187, C3312, and SDS-7). The 52 and $25 \mathrm{kDa}$ bands were much fainter than the $96 \mathrm{kDa}$ band, indicating that only a small proportion of $96 \mathrm{kDa}$ band was further cleaved (Fig. 4C). This extra cleavage reaction could be $\mathrm{Cls}$-mediated at R219/T222, which would generate polypeptides of the correct size and disulphide linkage, or it could be due to cleavage with a second protease contaminating one of the reagents. In this regard, there is no plasmin cleavage site that would generate fragments of this size (plasmin cleaves at KG [194-195] and KK [284-285]; 18). A secondary cleavage of $\mathrm{Cl}$-inh by $\mathrm{Cls}$ has not been documented in previous studies relying on SDSPAGE with Coomassie Blue staining to detect the reaction products. However, immunoblotting is $10^{2}$ - to $10^{3}$-fold more sensitive and therefore more likely to detect this secondary cleavage reaction. In contrast, $\mathrm{Cl}$-inh in plasma samples of the AAE patients studied displayed only a $96 \mathrm{kDa}$ band under reducing and nonreducing conditions (data not shown), suggesting that the cleavage of the $96 \mathrm{kDa}$ form was a feature of the in vitro system. Incubation of normal IgG with $\mathrm{Cl}$-inh and $\mathrm{Cls}$ in place of autoantibody did not result in $\mathrm{Cl}$-inh cleavage. Incubation of autoantibody with $\mathrm{Cl}$-inh in the absence of $\mathrm{Cls}$ did not result in $\mathrm{Cl}$-inh cleavage (Fig. $4 \mathrm{C}$ ).

\section{Stoichiometry of Autoantibody-Cl-inh-Cls Interactions}

Using a fixed concentration of Cls $(23.5 \mathrm{nM}$ in a final reaction volume of $3 \mathrm{ml}$ ) it was found that a concentration of $12.7 \mathrm{nM}$ of $\mathrm{Cl}$-inh produced approximately $50 \%$ inhibition of $\mathrm{Cls}$ activity $(48.3 \%, 49.7 \%$, and $48.8 \%$ in three separate 


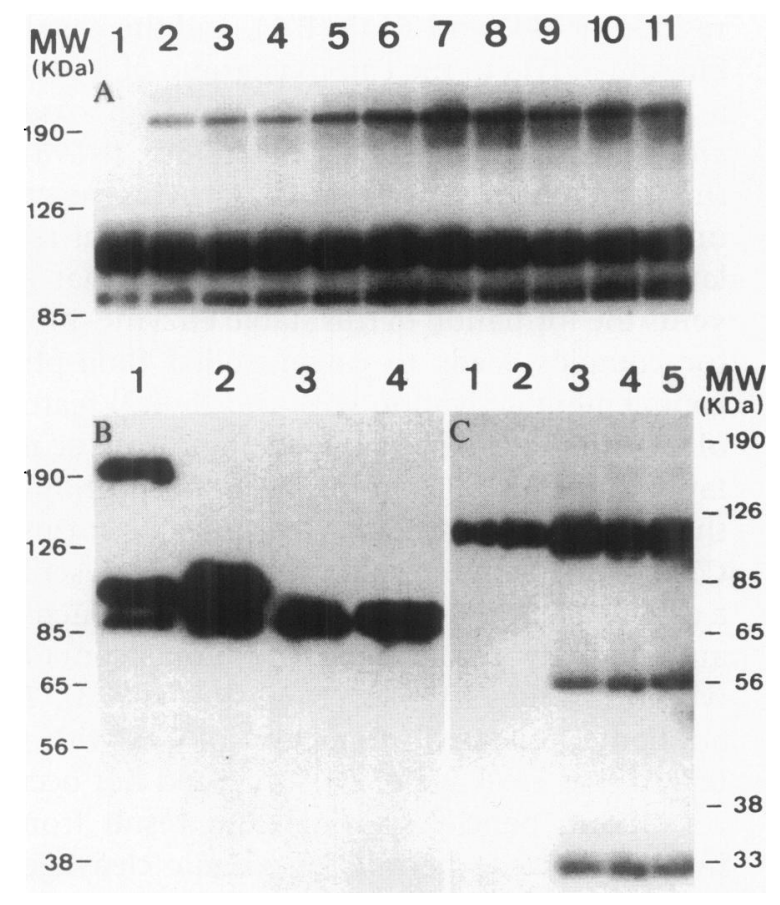

Fig. 4. Western blots of interactions of $\mathrm{Cl}$-inh, autoanti-C1-inh, and Cls. All protein reagents were in PBS and the reaction volumes were all 40 $\mu l$. (A). Western blot from nonreducing SDS-PAGE. The concentration of $\mathrm{Cl}$-inh was $1.4 \mu \mathrm{M}$ while the autoantibody was used at the $50 \%$ inhibitory concentration $(0.4 \mu \mathrm{M})$. The concentrations of $\mathrm{Cls}$ were varied. Reaction time of autoantibody with $\mathrm{Cl}$-inh was $2 \mathrm{hr}$ and that of the autoantibody-Cl-inh mixture with $\mathrm{Cls}$ was $3 \mathrm{hr}$ at $37^{\circ} \mathrm{C}$. The reactions were stopped by addition of sample buffer and samples were separated by SDS-PAGE $(7.5 \% \mathrm{w} / \mathrm{v}$ polyacrylamide). Proteins were transferred to nitrocellulose by blotting and detected by goat anti-human $\mathrm{Cl}$-inh and rabbit anti-goat IgG conjugated with horse radish peroxidase. $\mathrm{Cl}$-inh was detected using ECL reagents and the result is shown. The observed bands are: $>190 \mathrm{kDa}, \mathrm{Cls}-\mathrm{Cl}$-inh complex; $115 \mathrm{kDa}$, intact $\mathrm{Cl}$-inh; $96 \mathrm{kDa}$, a cleaved form of $\mathrm{Cl}$-inh. Lane l: $\mathrm{Cl}$-inh alone; lanes 2-11: $\mathrm{Cl}$-inh and Patient 1 autoantibody incubated for $2 \mathrm{hr}, 37^{\circ} \mathrm{C}$, which then continued for a further 3-hr incubation with different amounts of $\mathrm{Cls}$ : $0.3 \mu \mathrm{M}$ (lane 2); $0.4 \mu \mathrm{M}$ (lane 3); $0.6 \mu \mathrm{M}$ (lane 4); $0.7 \mu \mathrm{M}$ (lane 5); $0.8 \mu \mathrm{M}$ (lane 6); $1.0 \mu \mathrm{M}$ (lane 7); $1.2 \mu \mathrm{M}$ (lane 8); $1.3 \mu \mathrm{M}$ (lane 9); $1.5 \mu \mathrm{M}$ (lane 10), and $1.6 \mu \mathrm{M}$ (lane 11). (B) Western blot from nonreducing SDS-PAGE. The concentrations of $\mathrm{Cl}$-inh and autoantibody were 2.1 $\mu \mathrm{M}$ and $1.3 \mu \mathrm{M}$, respectively, and that of $\mathrm{Cls}$ was $8.8 \mu \mathrm{M}$ in a total reaction volume of $40 \mu \mathrm{l}$. The re-

experiments) (Fig. 5A). These ratios of $\mathrm{Cls}: \mathrm{Cl}$ inh are consistent with a reaction in which $100 \%$ inhibition of $\mathrm{Cls}$ is produced by an equimolar concentration of $\mathrm{Cl}$-inh; i.e., $11.8 \mathrm{nM} \mathrm{Cls}$ is inhibited by $12.7 \mathrm{nM} \mathrm{Cl-inh}$. Using concentra-

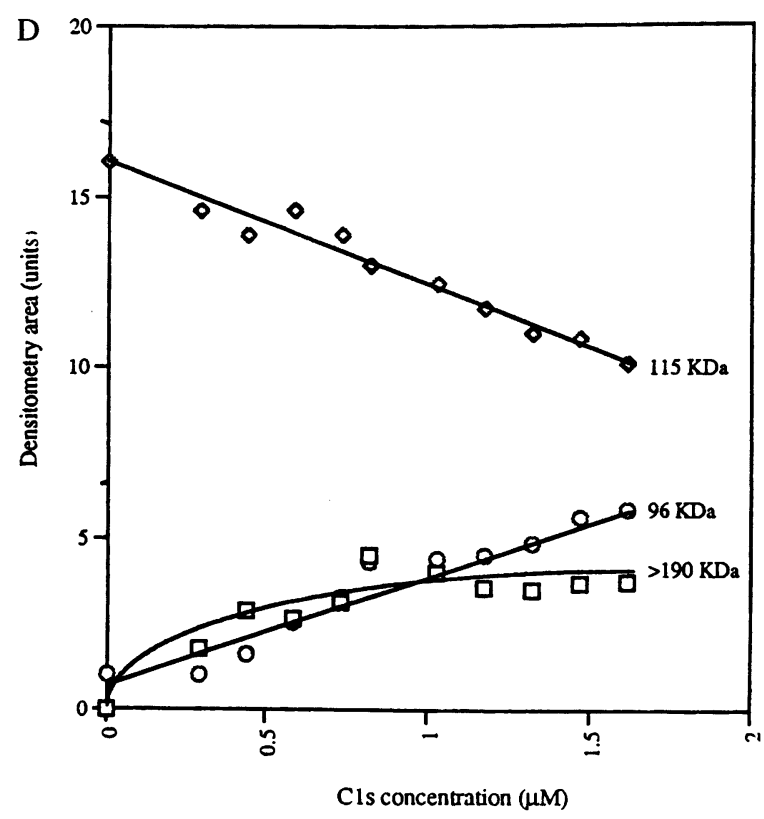

action conditions were the same as in A, except that incubation of autoantibody-Cl-inh mixture with $\mathrm{Cls}$ was for $6 \mathrm{hr}$ at $37^{\circ} \mathrm{C}$. Lane l: $\mathrm{Cl}$-inh and Cls; lane 2: $\mathrm{Cl}$-inh alone; lane 3: Patient 1 autoantibody and $\mathrm{C} 1$-inh and then C1s; lane 4: Patient 2 autoantibody and $\mathrm{Cl}$-inh and then C1s. (C) Western blot from reducing SDS-PAGE. Reaction concentrations of $\mathrm{Cl}$ inh, autoantibody, and C1s were $2.1 \mu \mathrm{M}, 1.3 \mu \mathrm{M}$, and $1.8 \mu \mathrm{M}$, respectively. Lane 1: $\mathrm{Cl}$-inh alone; lane 2: $\mathrm{Cl}$-inh and autoantibody; lanes 3-5: $\mathrm{Cl}$-inh and autoantibody were incubated for $2 \mathrm{hr}$ at $37^{\circ} \mathrm{C}$, then $\mathrm{Cls}$ was added and incubation continued for $1 \mathrm{hr}$ (lane 3), $3 \mathrm{hr}$ (lane 4), and $5 \mathrm{hr}$ (lane 5). This gel does not resolve the $105 \mathrm{kDa}$ and $96 \mathrm{kDa}$ bands effectively, so they appear (lanes 3-5) as a single broad band. Data shown in this figure were obtained with Patient 1 autoantibody but a similar results were obtained with Patient 2 autoantibody. (D) Scanning densitometry of the gel shown in Fig. 4A. As the concentration of $\mathrm{Cls}$ increased, the intensity (area under the curve) of the $115 \mathrm{kDa}$ band of native $\mathrm{Cl}$-inh decreased, while that of the $96 \mathrm{kDa}$ band (cleaved $\mathrm{Cl}$-inh) continued to increase. The intensity of the $190 \mathrm{kDa}$ band ( $\mathrm{Cls}$ - $\mathrm{Cl}$-inh complex) increased to reach a plateau level when the Cls concentration was approximately $1 \mu \mathrm{M}$. The density of the $190 \mathrm{kDa}$ band may be an underestimate of the amount of $\mathrm{Cls}-\mathrm{Cl}$-inh complex formed because of the possibility of inefficient transfer of higher molecular weight species from gel to membrane.

tions of $\mathrm{Cls}$ and $\mathrm{Cl}$-inh of $23.5 \mathrm{nM}$ and $12.7 \mathrm{nM}$, respectively, we determined that the autoantibody concentration that resulted in total loss of $\mathrm{Cl}$-inh activity was $13 \mathrm{nM}$ (26 $\mathrm{nM}$ antigen binding sites) in the reaction volume of $3 \mathrm{ml}$ (Fig. 5B, 

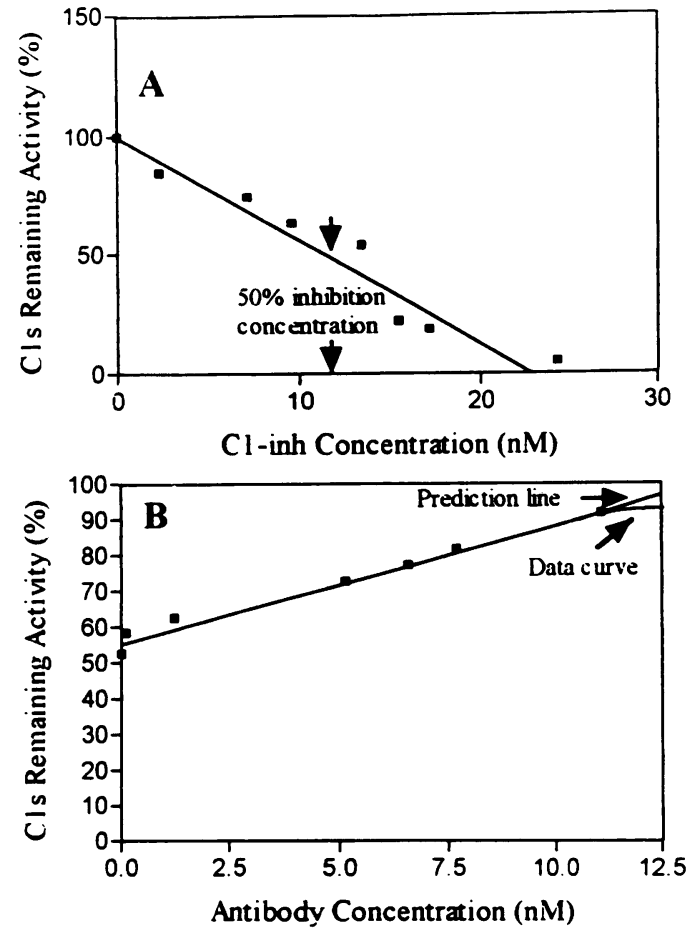

Fig. 5. Measurements of reaction stoichiometry of Cl-inh, Cls, and autoantibody. (A) The effect of $\mathrm{Cl}$-inh on $\mathrm{Cls}$. The concentration of $\mathrm{Cls}$ used in the assay was $23.5 \mathrm{nM}$ and that of $\mathrm{Cl}$-inh ranging from 0 to $24.4 \mathrm{nM}$ in a total reaction volume of $3 \mathrm{ml}$. The half-inhibitory concentration of $\mathrm{Cl}$-inh $(12.6 \mathrm{nM})$ is indicated by an arrow. The vertical axis in the plot is the remaining $\mathrm{Cls}$ activity calculated according to the enzyme activity assay described in Materials and Methods. (B) The effect of autoantibody on $\mathrm{Cl}$-inh. The concentrations of $\mathrm{Cls}$ and $\mathrm{Cl}$-inh used in the assay were those for half-inhibitory conditions as seen in A and that of autoantibody ranged from 0 to $5 \mu \mathrm{g}$ in a total reaction volume of $3 \mathrm{ml}$. The complete inhibitory concentration of autoantibody is .13 nm (arrows). Data shown were obtained with Patient 1 autoantibody but similar results were obtained with Patient 2 autoantibody.

arrows). Within the experimental limits of measurement of concentrations, this is likely to indicate a 1:1 stoichiometry for the $\mathrm{Cl}$-inh-autoantibody interaction. The higher autoantibody $\mathrm{Cl}$ inh molar ratio required to inhibit $\mathrm{Cl}$-inh activity in this experiment, compared with the dose-response study shown in Fig. lb, may be related to the far lower concentration of $\mathrm{Cl}$-inh used in this study.

\section{Discussion}

The interaction of $\mathrm{Cls}$ with $\mathrm{Cl}$-inh results in cleavage of the latter between the reactive site residue ( $\mathrm{R} 444)$ and $\mathrm{T} 445\left(\mathrm{P}^{\prime} 1\right)$, and the covalent binding of $\mathrm{Cls}$ to the carboxyl group of R444 via a transacylation reaction involving an oxygen atom of the active site serine residue (S195) of the light chain of $\mathrm{Cls}(19-21)$. This reaction inhibits $\mathrm{C} 1 \mathrm{~s}$ activity permanently and thus regulates $\mathrm{Cl}$ activity (2). Any mechanism that prevents the formation of this stable enzyme-inhibitor complex leads to uncontrolled fluid-phase complement activation with the clinical features of $\mathrm{Cl}$-inh deficiency (angioedema). Genetic mutations resulting in amino acid substitutions at the reactive site residue yield inactive forms of Cl-inh (5). Mandle et al. (23) recently described a case of acquired $\mathrm{Cl}$-inh deficiency in which the autoantibody recognized an epitope contained within residues P15-P1 (T430-R444) (23). This antibody prevented interaction of $\mathrm{Cls}$ with $\mathrm{Cl}$ inh so that cleavage of $\mathrm{Cl}$-inh could not occur.

$\mathrm{Cl}$-inh deficiency could also result from a mechanism that permits enzymatic cleavage of $\mathrm{Cl}$-inh by $\mathrm{Cls}$ but prevents formation of the stable enzyme-inhibitor complex, thus converting $\mathrm{Cl}$-inh to a substrate. Mutations in the proximal hinge region of $\mathrm{Cl}$-inh, A434E (24), V432E, and A434T (25), convert $\mathrm{Cl}$-inh to a substrate for $\mathrm{Cls}$. The mutant $\mathrm{Cl}$-inh species are cleaved to forms with a molecular weight of $96 \mathrm{kDa}$. The data presented here suggest that the $\mathrm{Cl}$-inh autoantibodies studies produce $\mathrm{Cl}$-inh deficiency by such a mechanism. However, these autoantibodies recognize the epitope QQPF and/or LLVF, both of which are C-terminal to the $\mathrm{R} 444$ reactive site residue (9).

The first set of experiments, using ${ }^{125} \mathrm{I}$-labeled $\mathrm{Cls}$, showed that although the autoantibodies prevented the formation of a stable enzyme-inhibitor complex, they were unable to dissociate the complex, even with a large (10fold) molar excess of autoantibody. Thus $\mathrm{Cl}$-inh autoantibodies must act prior to the formation of the enzyme-inhibitor complex.

In the second set of experiments, incubation of $\mathrm{Cl}$-inh with autoantibodies prior to exposure to $\mathrm{Cls}$ resulted in cleavage of $\mathrm{Cl}$-inh, with the production of the $96 \mathrm{kDa}$ form and the failure to form a Cls-Cl-inh complex. These two sets of experiments show that in the presence of the autoantibodies, Cls is able to cleave $\mathrm{Cl}$-inh, probably between the reactive site residue (R444) and T445. This cleavage is not followed by the formation of a stable enzyme-inhibitor complex. Thus Cl-inh inhibitory activity is lost and C1s maintains its active form after it dissociates from cleaved form $\mathrm{Cl}$-inh-Cls complex. 
The effect of autoantibodies in "converting" Clinhibitor from an inhibitor to a substrate is entirely consistent with previous findings (26). The site of interaction of autoantibody with $\mathrm{Cl}$-inh has now been clarified (9), permitting more detailed analysis of the mechanism.

The dose-response studies using ${ }^{125}$ I-labeled $\mathrm{Cls}$ and the data from kinetic assays show that for complete abrogation of Cl-inh activity, equimolar concentrations of autoantibody and $\mathrm{Cl}$-inh were required. Interestingly, the serum molar concentrations of the two autoantibodies studies were similar to those of C1-inh (9). There are at least three explanations as to why anti-Clinh autoantibodies result in the production of cleaved inactive $\mathrm{Cl}$-inh. The possibility that the autoantibodies themselves have enzymatic activity was excluded by the demonstration that cleavage of $\mathrm{Cl}$-inh only occurred when $\mathrm{Cls}$ was present in addition to the autoantibody (Figs. 3 and 4). It is also possible that the binding of the anti-Cl-inh autoantibody produces a conformational change in $\mathrm{Cl}$-inh, which makes it susceptible to proteolysis by enzymes other than those which it usually regulates. Although we have no direct evidence to show that this does not occur in vivo, the observations that the $96 \mathrm{kDa}$ cleaved form of $\mathrm{Cl}$-inh circulates in vivo and is generated from the incubation of $\mathrm{Cl}$-inh, anti-Cl-inh autoantibody, and $\mathrm{Cls}$ in vitro suggest that this is not the case. Our data support the view that the binding of anti-Cl-inh autoantibody to $\mathrm{Cl}$-inh converts $\mathrm{Cl}$-inh from a pseudosubstrate to a substrate. As a result of the autoantibody being bound to $\mathrm{Cl}$-inh, the bond formed between $\mathrm{S} 195$ of $\mathrm{Cls}$ and $\mathrm{R} 444$ of $\mathrm{Cl}$-inh is destroyed, probably because the bond is attacked by reactive small molecules in the solvent, i.e., by hydrolysis. In other experiments (27), we have shown that $\mathrm{Cls}$, like anti-Cl-inh autoantibodies, binds to peptide 3 , which suggests that the distal hinge region of $\mathrm{Cl}$-inh contains a secondary binding site for $\mathrm{Cls}$. We hypothesize that the interaction of $\mathrm{Cls}$ with this secondary binding site is essential for the formation of a stable $\mathrm{Cls}$ - $\mathrm{Cl}$-inh complex. Binding of the autoantibody to $\mathrm{Cl}$-inh would prevent the interaction of $\mathrm{Cls}$ with the secondary binding site and expose the bonding atoms to the solvent, resulting in their hydrolysis so that a stable complex does not form.

The observation that even with a 4-fold molar excess of $\mathrm{Cls}$ over $\mathrm{Cl}$-inh, the latter was not completely incorporated into the SDS-stable enzyme-inhibitor complex, suggests that a proportion of the $\mathrm{Cl}$-inh preparation was in a confor- mationally altered form. However, complete cleavage of $\mathrm{Cl}$-inh occurred while $\mathrm{C} 1$-inh autoantibody was preincubated with $\mathrm{Cl}$-inh, which suggests that the autoantibody can also produce a conformational change in $\mathrm{Cl}$-inh, rendering it susceptible to proteolysis by $\mathrm{Cls}$. An alternative explanation is that a proportion of the $\mathrm{Cls}-\mathrm{Cl}$ inh complexes formed are reversible and that the autoantibody drives the reaction to the stage at which it is irreversible.

The observation that peptides 2 and 3, but not peptide 1 , inhibited the effect of the autoantibody on $\mathrm{Cls}-\mathrm{Cl}$-inh complex formation confirms our previous conclusion (8) that both peptides 2 and 3 contain an epitope recognized by the autoantibody. Furthermore, they suggest that both of these peptides might have therapeutic value in the management of patients with AAE with Cl-inh autoantibodies of the specificity of those described in this study. Our original report described six patients; since then, we have diagnosed a further six, all of whom have autoantibodies that react strongly with peptide 3 and to a lesser extent, with peptide 2 , suggesting that this specificity is common to type II AAE.

\section{Acknowledgments}

This work was supported by a grant from the Wellcome Trust.

\section{References}

1. Davis, AE. (1988) Cl-inhibitor and hereditary angioneurotic edema. Annu. Rev. Immunol. 6: 595628.

2. Perkins SJ, Smith KF, Amatayakul S, Ashford D, Rademacher TW, Dwek RA, Lachmann PJ, Harrison RA. (1990) The two-domain structure of the native and reaction centre cleaved forms of $\mathrm{Cl}$ inhibitor of human complement by neutron scattering. J. Mol. Biol. 214: 751-768.

3. Ziccardi RJ. (1985) Demonstration of the interaction of native $\mathrm{Cl}$ with monomeric immunoglobulins and Cl-inhibitor. J. Immunol. 134: 25592563.

4. Sim RB, Arland GJ, Colomb MG. (1979) Cl-inhibitor dependent dissociation of human complement component $\mathrm{Cl}$ bound to immune complexes. Biochem. J. 179: 449-457.

5. Stein PE, Carrell RW. (1995) What dysfunctional serpins tell us about molecular mobility and disease. Structural Biol. 2: 96-113.

6. Geha RS, Quinti I, Ansten KF, Cicardi M, Sheffer A, Rosen FS. (1985) Acquired Cl-inhibitor deficiency associated with anti-idiotype antibody to 
monoclonal immunoglobulins. N. Engl. J. Med. 312: $534-540$.

7. Jackson J, Sim RB, Whelan A, Feighery C. (1986) An IgG autoantibody which inactivates $\mathrm{Cl}$-inhibitor. Nature 323: 722-724.

8. Alsenz J, Bork K, Loos M. (1987) Autoantibodymediated acquired deficiency of $\mathrm{Cl}$-inhibitor. N. Engl. J. Med. 316: 1360-1366.

9. He S, Tsang S, North J, Chohan N, Sim RB, Whaley K. (1996) Epitope mapping of Cl-inhibitor autoantibodies from patients with acquired $\mathrm{Cl}$ inhibitor deficiency. J. Immunol. 154: 2009-2013.

10. Hudson L, Hay F. (1989) The basic techniques. In: Practical Immunology, 3rd ed. Blackwell Scientific Publications, Oxford, pp. 1-3.

11. Pilatte Y, Hammer CH, Frank MM, Fries LF. (1989) A new simplified procedure for Cl-inhibitor preparation: A novel use for Jacalin-agarose. J. Immunol. Methods 120: 37-43.

12. Sim RB. (1981) The human complement system serine proteases $\mathrm{Clr}$ and $\mathrm{Cls}$ and their proenzymes. Methods Enzymol. 80: 26-42.

13. Harrison RA. (1983) Human Cl-inhibitor: Improved isolation and preliminary structural characterisation. Biochemistry 22: 5001-5007.

14. Gigli I, Porter RR, Sim RB. (1976) The unactived form of the first component of human complement, C1. Biochem J. 157: 541-548.

15. Markwell MAK. (1982) A new solid-state reagent to iodinate proteins. I. conditions for the efficient labelling of antiserum. Anal. Biochem. 125: 427432.

16. Laemmli UK. (1970) Cleavage of structural proteins during the assembly of the head of the bacteriophage T4. Nature 227: 680-685.

17. Towbin H, Staehelin T, Gordon J. (1979) Electrophoretic transfer of proteins from polyacrylamide gel to nitrocellulose sheets: Procedure and some applications. Proc. Natl. Acad. Sci. U.S.A. 76: 43504354.

18. Wallace EM, Perkins SJ, Sim RB, Willis AC, Feighery C, Jackson J. (1997) Degradation of C1-Inhibitor by Plasmin: Implications for the Control of Inflammatory Processes. Molec. Med. 3: 385-396.

19. Sim RB, Reboul A. (1981) Preparation and prop- erties of human C1-inhibitor. Methods Enzymol. 80: 43-53.

20. Cohen GH, Silverton EW, Davis DR. (1981) Refined crystal structure of $\gamma$-chymotrypsin at $1.9 \AA$ resolution. Comparison with other pancreatic serine proteases. J. Mol. Biol. 148: 449-479.

21. Birktoft JJ, Blow DM. (1972) Structure of crystalline $\alpha$-chymotrypsin. V. The atomic structure of tosyl- $\alpha$-chymotrypsin at $2 \AA$ resolution. J. Mol. Biol. 68: 187-240.

22. Fothergill J, Kemp G, Paton N, Carter P, Gray P. (1989) The structure of human Clr and Cls and their relationship to other serine proteases. $\mathrm{Be}$ hring Inst. Mitt. 84: 72-79.

23. Mandle R, Baron C, Roux E, Sundal R, Gelfand J, Aulak K, Davis AE, Rosen FS, Bing D. (1994) Acquired $\mathrm{Cl}$-inhibitor deficiency as a result of an autoantibody to the reactive centre region of $\mathrm{Cl}$ inhibitor. J. Immunol. 152: 4680-4685.

24. Skriver K, Wikoff WR, Patston PA, Tauske F, Schapira M, Kaplan AP, Bock SC. (1991) Substrate properties of $\mathrm{Cl}$-inhibitor Ma (alanine 434 $\rightarrow$ glutamic acid). J. Biol. Chem. 266: 9216-9221.

25. Davis AE, Aulak KS, Parad RB, Stecklein HP, Eldering E, Hack LE, Kramer J, Strunk RC, Rosen FS. (1992) Cl-inhibitor hinge region mutations produce dysfunction by different mechanisms. Nature Genet. 1: 354-358.

26. Jackson J, Sim RB, Whaley K, Feighery C. (1989) Autoantibody mediated cleavage of novel $\mathrm{Cl}$-inhibitor by purified $\mathrm{Clr}, \mathrm{Cls}$ and plasmin. J. Clin. Invest. 83: 698-707.

27. He S, Sim RB, Whaley K. (1997) A secondary C1s interaction site on $\mathrm{Cl}$-inhibitor is essential for formation of a stable enzyme-inhibitor complex. FEBS Lett. 405: 42-46.

28. Ishizaki E, Yoshioka Y, Mori Y, Koyama J. (1976) Isolation of two forms of activated Cls, a subcomponent of the first component of rabbit complement. J. Biochem. 80: 1423-1427.

29. Mori Y, Ueda E, Takenchi T, Taniuchi S, Koyama J. (1980) Proteolytic cleavage of an activated subcomponent of the first component of rabbit complement, C1s. J. Biochem. 87: 1757-1763. 